\title{
RESEARCH
}

Open Access

\section{Induction of immunogenic cell death in radiation-resistant breast cancer stem cells by repurposing anti-alcoholism drug disulfiram}

Ting Sun ${ }^{1,2}$, Wei Yang ${ }^{3,4}$, Sneh M. Toprani ${ }^{3}$, Wei Guo ${ }^{1}$, Lile He ${ }^{1}$, Albert B. DeLeo ${ }^{1}$, Soldano Ferrone ${ }^{1,5}$, Gong Zhang ${ }^{1}$, Enwen Wang ${ }^{1}$, Zunwen Lin ${ }^{1}$, Pan Hu${ }^{1}$ and Xinhui Wang ${ }^{1 *}$ (D)

\begin{abstract}
Background: The current successful clinical use of agents promoting robust anti-tumor immunity in cancer patients warrants noting that radiation therapy (RT) induces immunogenic cell death (ICD) of tumor cells, which can generate anti-tumor immune responses. However, breast cancer stem cells (BCSCs) are resistant to RT and RT alone usually failed to mount an anti-tumor immune response.

Methods: High aldehyde dehydrogenase activity $(\mathrm{ALDH})^{\text {bright }}$ and $\mathrm{CD} 44^{+} / \mathrm{CD} 24^{-} / \mathrm{ESA}^{+}$cancer cells, previously shown to have BCSC properties, were isolated from human MDA-MB-231 and UACC-812 breast cancer cell lines by flow cytometer. Flow sorted BCSCs and non-BCSCs were further tested for their characteristic of stemness by mammosphere formation assay. Induction of ICD in BCSCs vs. non-BCSCs in response to different in vitro treatments was determined by assessing cell apoptosis and a panel of damage-associated molecular pattern molecules (DAMPs) by flow and enzyme-linked immunosorbent assay (ELISA).

Results: We found that ionizing radiation (IR) triggered a lower level of ICD in BCSCs than non-BCSCs. We then investigated the ability of disulfiram/cooper (DSF/Cu) which is known to preferentially induce cancer stem cells (CSCs) apoptosis to enhance IR-induced ICD of BCSCs. The results indicate that DSF/Cu induced a similar extent of IDC in both BCSCs and non-BCSCs and rendered IR-resistant BCSCs as sensitive as non-BCSCs to IR-induced ICD. IR and DSF/Cu induced ICD of BCSCs could be partly reversed by pre-treatment of BCSCs with a reactive oxygen species (ROS) scavenger and XBP1s inhibitors.

Conclusion: DSF/Cu rendered IR-resistant BCSCs as sensitive as non-BCSCS to IR-induced ICD. Our data demonstrate the potential of IR and DSF/Cu to induce ICD in BCSCs and non-BCSCs leading to robust immune responses against not only differentiated/differentiating breast cancer cells but also BCSCs, the root cause of cancer formation, progression and metastasis.
\end{abstract}

Keywords: Breast cancer, Stem cells, Immunogenic cell death, Radiation, Disulfiram, Copper, Reactive oxygen species, IRE1a, XBP1s, Signaling pathway

\footnotetext{
* Correspondence: Xwang30@mgh.harvard.edu

'Division of Surgical Oncology, Department of Surgery, Massachusetts

General Hospital, Harvard Medical School, Boston, USA

Full list of author information is available at the end of the article
}

(c) The Author(s). 2020 Open Access This article is distributed under the terms of the Creative Commons Attribution 4.0 International License (http://creativecommons.org/licenses/by/4.0/), which permits unrestricted use, distribution, and reproduction in any medium, provided you give appropriate credit to the original author(s) and the source, provide a link to the Creative Commons license, and indicate if changes were made. The Creative Commons Public Domain Dedication waiver (http://creativecommons.org/publicdomain/zero/1.0/) applies to the data made available in this article, unless otherwise stated. 


\section{Background}

Breast cancer is the most common cancer among women. The development of more effective therapeutic regimens has contributed to improved outcomes for breast cancer patients. Nevertheless, recurrence and metastasis often happen after comprehensive treatments. Emerging evidence indicates that preexisting CSCs, a small subpopulation of cancer cells that exist within heterogeneous tumors, are responsible for treatment resistance and subsequent progression, recurrence, and metastasis of cancer [1-4].

CSCs express two fundamental characteristics: the capacity for self-renewal and the ability to efficiently reconstitute differentiated tumors. In contrast, non-stem cancer cells, the differentiated/ differentiating progeny that constitute a substantial part of the tumor, are radiosensitive, which accounts for the short-term regression of tumors following RT.

Tumor cells expressing elevated levels of intracellular aldehyde dehydrogenase (ALDH) in human and mouse breast cancer have been convincingly shown to be BCSCs $[5,6]$. The enhanced ALDH activity in these cells eliminates genotoxic aldehydes contributing to their resistance to most standard cancer therapies. CSC research is facilitated by the ability to detect and isolate these cells by flow cytometry using the ALDEFLUOR reagent to measure ALDH enzymatic activity $[6,7]$. ALDH ${ }^{\text {bright }}$ cells are defined as those $\mathrm{ALDH}^{+}$cells with twice the mean fluorescence intensity (MFI) of the bulk $\mathrm{ALDH}^{+}$ cell population.

DSF is an irreversible pan-ALDH inhibitor [8, 9] and FDA approved drug for treatment of alcoholism since 1951 [10]. It's uses results in accumulation of, in particular, acetaldehyde, and unpleasant effects in individuals when they consume alcohol. Interestingly and strikingly, an epidemiological study covering a 13 -year period indicated that treatment of alcoholism in cancer patients with DSF significantly reduced their risk of death from cancer [11].

Studies have shown that in cells DSF converts to diethyldithiocarbamate (deDTC) and that two molecules of deDTC bind to one molecule of copper $\left(\mathrm{Cu}^{2+}\right)$ to form the $\mathrm{Cu}$ [deDTC] complex (DSF/Cu) [12-14]. It is known that $\mathrm{DSF} / \mathrm{Cu}$ is an effective proteasome inhibitor resulting in inhibition of $\mathrm{NF}-\mathrm{KB}[12,15]$ and activation of endoplasmic reticulum (ER)-stress through upregulation of the inositol requiring-enzyme 1 alpha (IRE1 $\alpha$ )$\mathrm{X}$-box-binding protein 1 (XBP1) axis leading to autophagic apoptosis [16]. It was demonstrated that $\mathrm{DSF} / \mathrm{Cu}$ is a potent radio- and chemo-sensitizer for breast and pancreatic cancer through targeting CSCs $[6,17]$.

IR has been reported as a strategy to induce ICD in a variety of tumor cells [18-23]. The phenomenon of ICD, the emission of immuno-stimulatory signals by dying apoptotic cells, is induced by chemotherapeutic drugs such as anthracyclines, oxaliplatin, bortezomib, or radiotherapy and photodynamic therapy [24-26] can lead to effective antitumor immune responses [27-31]. The molecular characteristics of ICD are referred to as the release or cell-surface expression of highly immunostimulatory DAMPs [32] such as i) the surface exposure of calreticulin (CRT) and heat shock proteins (HSPs), ii) extracellular secretion of adenosine triphosphate (ATP), and iii) passive release of high mobility group protein $\mathrm{B} 1$ (HMGB1). These molecules stimulate antigen presenting cells (APCs) and activate dendritic cells can lead to the subsequent development and activation of tumor-specific effector T cells and memory $\mathrm{T}$ cells [32].

The results of an investigation of ICD of BCSCs and non-BCSCs induced by radiation and/or DSF/Cu are reported here. BCSCs present in two well-established human breast cancer cell lines, MDA-MB-231 and UACC812 , identified and isolated by flow cytometry as either $\mathrm{ALDH}^{\text {bright }}$ or $\mathrm{CD}_{4} 4^{+} / \mathrm{CD} 24^{-} / \mathrm{ESA}^{+}$cells $[5,6,33]$ were used in this study. Induction of ICD of both types of BCSC populations and non-BCSCs by radiation and DSF/Cu was monitored by apoptosis and expression/release of DAMPs. In addition, the roles of intracellular ROS and the IRE1 $\alpha / \mathrm{XBP} 1$ s pathway, both of which are involved in $\mathrm{DSF} / \mathrm{Cu}$ induced apoptosis of breast cancer cells $[15,16]$ in inducing ICD in BCSCs was studied.

\section{Materials and methods \\ Cell culture}

Human breast cancer cell lines, MDA-MB-231 and UACC-812 were obtained from the Duke Comprehensive Cancer Center Cell Culture Facility and the American Type Culture Collection (ATCC), respectively. MDA-MB-231 cells were cultured in high glucose DMEM (Corning Incorporated, NY, USA), and UACC812 cells were cultured in RPMI 1640 (Corning) with $10 \%$ fetal bovine calf serum (FBS) (Gemini Bio-Products, CA, USA) at $37^{\circ} \mathrm{C}$ in a humidified atmosphere of $5 \%$ $\mathrm{CO}_{2}$. Sorted cells were seeded and incubated overnight in 24-well plates at density of $5 \times 10^{4} /$ well in $0.5 \mathrm{~mL}$ of the same medium with $20 \%$ FBS and $1 \%$ penicillin and streptomycin (Corning).

\section{Fluorescence-activated cell sorting (FACS)}

To sort the BCSC subpopulations in the human breast cancer MDA-MB-231 and UACC-812 cell lines, 5-10 x $10^{7}$ cells were used at a time. ALDH assay kit from STEMCELL Technologies Inc. (Vancouver, BC, Canada), the antibodies for cell surface markers CD44, CD24 and ESA were FITC- conjugated anti-human CD44 antibody (clone BJ18), PE conjugated anti-human CD24 antibody (clone ML5), APC conjugated anti-human ESA (EpCAM) antibody (clone 9C4) from Biolegend 


\section{A. Sorting BCSCs subpopulations}

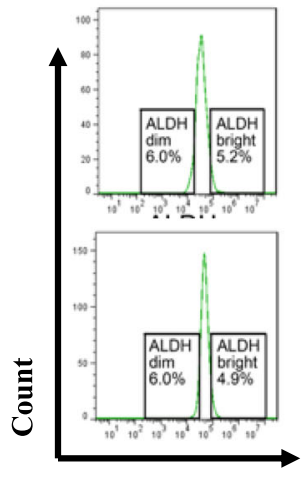

ALDH

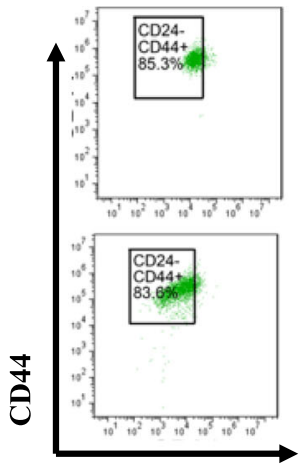

CD24

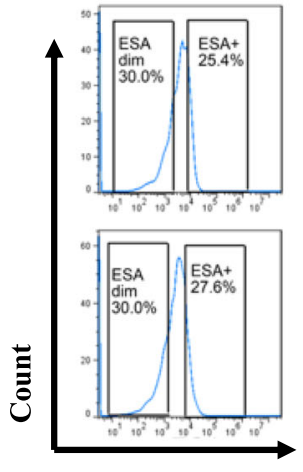

ESA
MDA-MB-231

UACC-812

\section{B. ALDH1A1 mRNA expression}

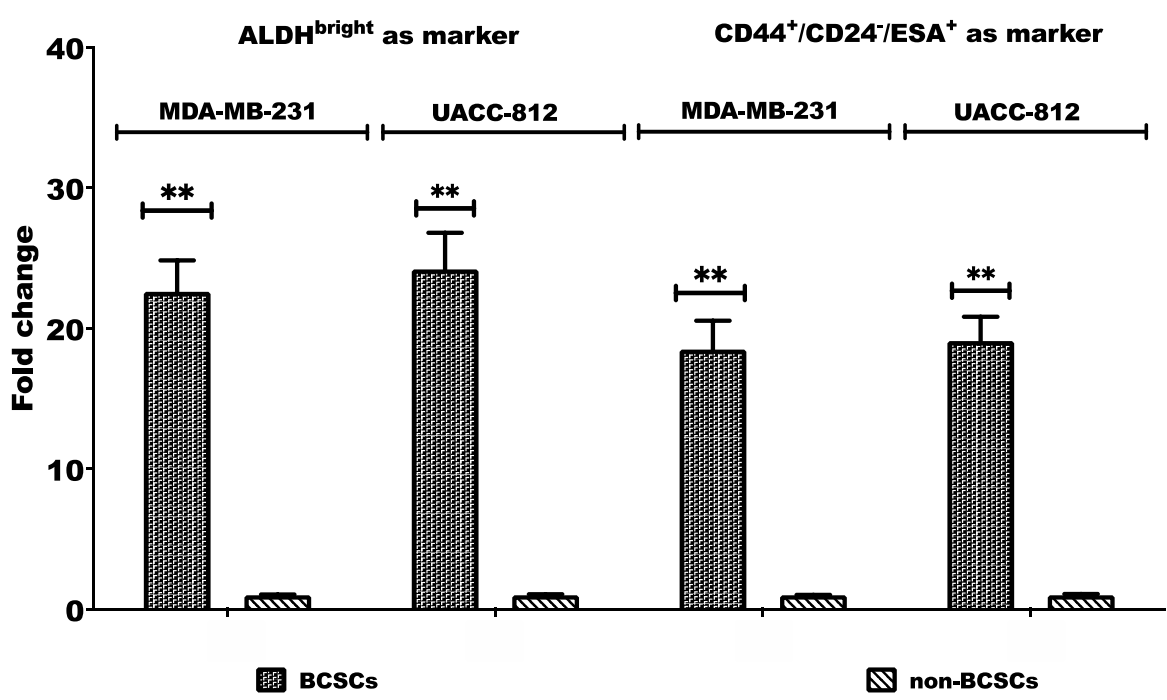

C. Mammosphere formation

MDA-MB-231

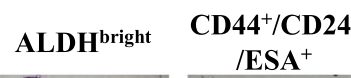

BCSCs

nonBCSCs

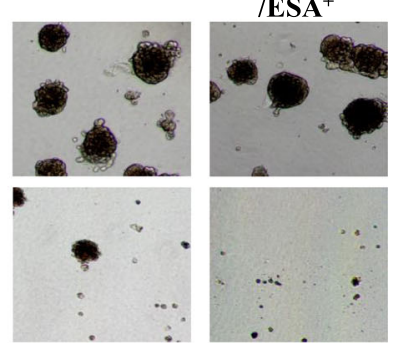

ALDH $^{\text {bright }}$
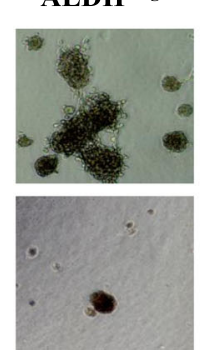

UACC-812

$\mathrm{CD} 44^{+} / \mathrm{CD}^{-} 4^{-}$

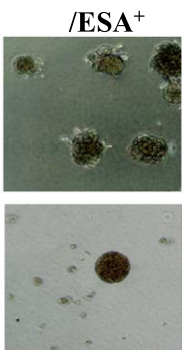

Fig. 1 Identification and sorting of BCSCs using flow cytometry from the human breast cell lines. (a) Sorting of BCSCs identified as either $\mathrm{ALDH}^{\text {bright }}$ or CD44 ${ }^{+} / \mathrm{CD} 24^{-} / \mathrm{ESA}^{+}$cells from MDA-MB-231 and UACC-812 cell lines (b) Sorted ALDH ${ }^{\text {bright }}$ as well as CD44 ${ }^{+} / \mathrm{CD}_{2} 4^{-} / \mathrm{ESA}^{+} \mathrm{BCSC}$ expressed greater levels of ALDH1A1 mRNA than in non-BCSCs (c) Mammosphere formation from sorted BSCSs and non-BSCSs 
A. Apoptotic effect
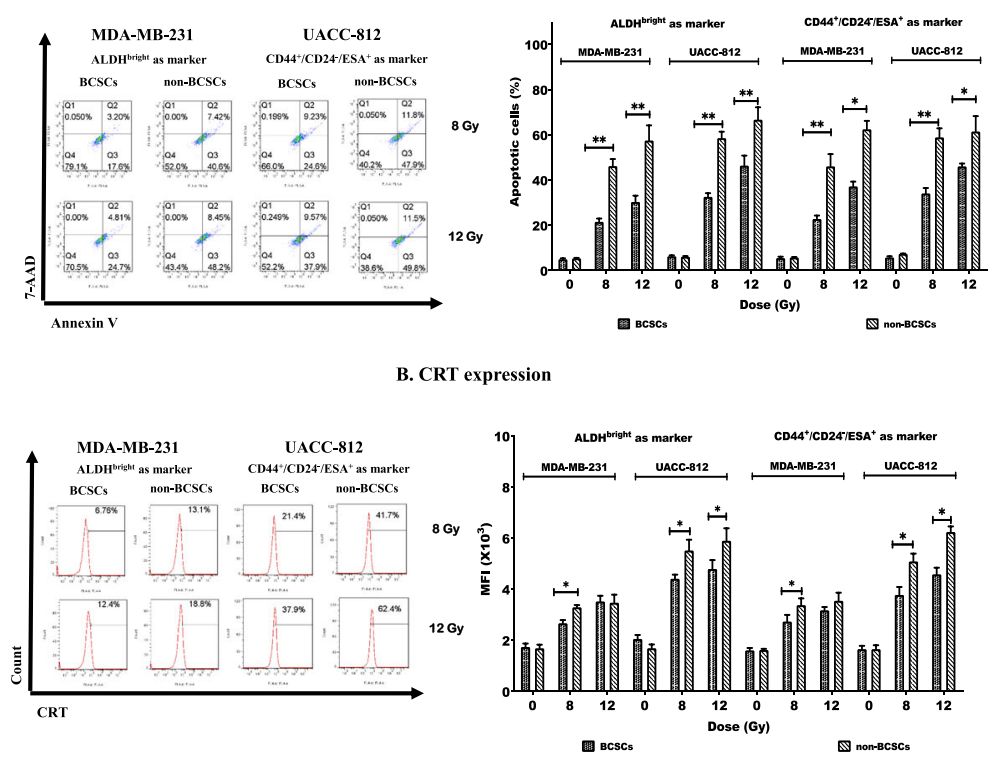

C. HSP90 expression

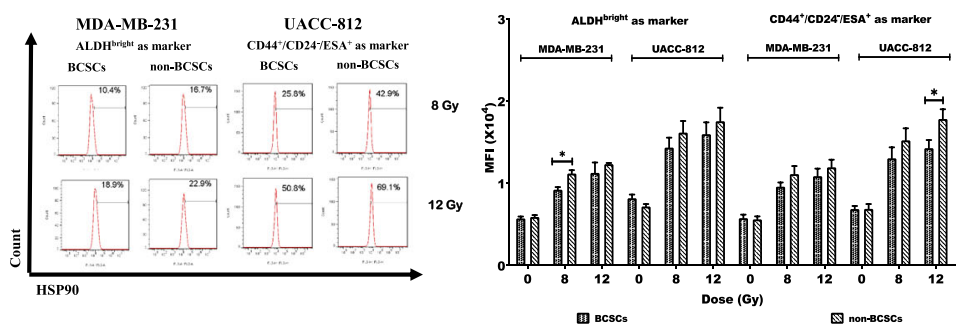

D. Intracellular ATP level
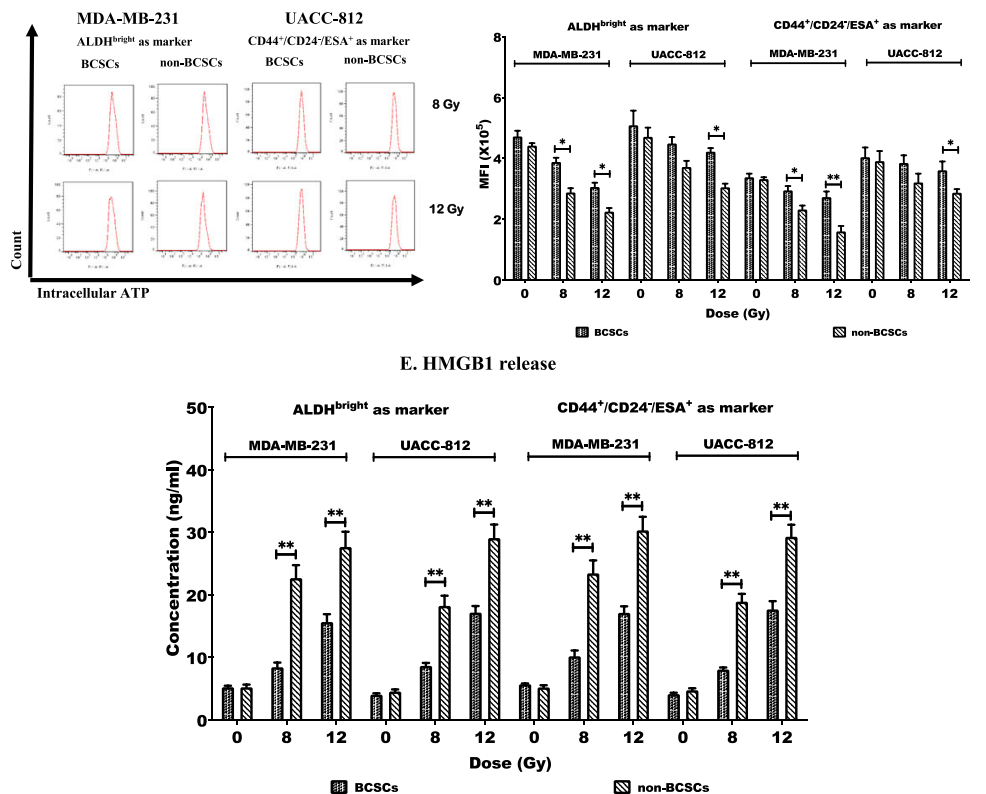

Fig. 2 (See legend on next page.) 
(See figure on previous page.)

Fig. 2 Radiation induced a low level of ICD in BCSCs than in non-BCSCs. Sorted cells were treated with IR at 8 or 12 Gy and cultured. Then cells and/or culture supernatants were collected at indicated times post IR and used for analyses of ICD by flow cytometry and ELISA. (a) Apoptotic cells were quantitated $24 \mathrm{~h}$ post-IR using AnnexinV/7-AAD staining (left panel). Percentages of apoptotic cells are indicated (right panel). (b) Percentages of cells expressing CRT were detected $8 \mathrm{~h}$ post IR (left panel) and their mean fluorescence intensity (MFI) values are shown (right panel). (c) Percentages of cells expressing HSP90 were detected $8 \mathrm{~h}$ post IR (left panel) and their MFI values are shown (right panel). (d) Levels of intracellular ATP were measured $1 \mathrm{~h}$ post-IR (left panel) and their MFI values are shown (right panel). (e) Concentrations of HMGB1 release were determined in supernatants collected at $24 \mathrm{~h}$ post-IR. *indicates $p<0.05$, **indicates $p<0.01$

(Dedham, MA, USA) were used to stain cells. For sorting ALDH ${ }^{\text {bright }}$ cells, cells were incubated with ALDEFLUOR $^{\oplus}$ reagent with or without ALDH inhibitor N,Ndiethylaminobenzaldehyde (DEAB) (STEMCELL) at $37^{\circ} \mathrm{C}$ for $1 \mathrm{~h}$ according to the manufacturer's instructions. For sorting CD $44^{+} / \mathrm{CD} 24^{-} / \mathrm{ESA}^{+}$cells, cells were incubated with the 3 -antibody cocktail at $4{ }^{\circ} \mathrm{C}$ for $15 \mathrm{~min}$ in the dark. Dead cells were excluded by 7-AAD staining. Stained cells were analyzed by FACSAria II and sorted by BD FACSAria I sorters at HSCI-CRM Flow Cytometry Core Facility, Massachusetts General Hospital.

\section{Real-time quantitative reverse transcription PCR (qRT-} PCR)

Sorted ALDH ${ }^{\text {bright }}$ and ALDH ${ }^{\text {dim }}$ cells were used for SYBR Green -based qRT-PCR to detect the mRNA levels of ALDH1A1 with primers (forward, 5'-GGAGGA AACCCTGCCTCTTTT-3' and reverse, 5' ${ }^{\prime}$-TTGGAA GATAGGGCCTGCAC-3') as described [34, 35].

\section{Mammosphere formation assay}

Sorted cells $\left(1 \times 10^{3}\right.$ cells $)$ were seeded in a 24-well ultra-low adherent plate (Corning) in $0.5 \mathrm{~mL}$ of mixed medium to perform sphere formation detection. The medium contained 32\% MethoCult medium, 20\% MammoCult basal human medium with a final concentration of $2 \%$ MammoCult proliferation supplements and $48 \%$ DMEM supplemented with final concentrations of 100 $\mathrm{pg} / \mathrm{mL}$ EGF, $50 \mathrm{ng} / \mathrm{mL}$ bFGF, $5 \mathrm{ng} / \mathrm{mL}$ stem cell factor, $1 \mu \mathrm{M}$ hydrocortisone, and $5 \mathrm{mg} / \mathrm{mL}$ insulin, all obtained from STEMCELL Technologies. The cells were cultured at $37^{\circ} \mathrm{C}$ in a $1 \% \mathrm{O}_{2}$ and $5 \% \mathrm{CO}_{2}$ humidified atmosphere for $14 \mathrm{~d}$. The number of tumor spheres was counted under microscope.

\section{Chemical reagents, in vitro cell treatment and radiation}

Tetraethylthiuram disulfide (disulfiram, DSF) and Copper (II) chloride $(\mathrm{Cu})$ were purchased from SigmaAldrich. DSF was dissolved in DMSO, and $\mathrm{Cu}$ was dissolved in Milli-Q water. The sorted cells were treated with $\mathrm{DSF} / \mathrm{Cu}$ in the concentration of $0.15 / 1 \mu \mathrm{M}$. This low dose was chosen based on titration experiments in order to obtain sufficient cells for the subsequent experimental analyses. IR was performed with single doses of $8 \mathrm{~Gy}$ or $12 \mathrm{~Gy}$. The X-RAD 320 Biological Irradiator (Precision X-ray, Inc., CT, USA) was used for IR experiments in this study.

\section{Flow cytometric analyses for apoptotic cells, cell surface expression of CRT and HSP90}

Apoptotic cells were identified using the Annexin V/ Dead Cell Apoptosis Kit (Biolegend) according to the manufacturer's instructions. The adherent cells were trypsinized, washed with PBS and resuspended in the binding buffer included in the Kit, then stained with FITC-Annexin V and 7-AAD for $15 \mathrm{~min}$ at $4{ }^{\circ} \mathrm{C}$ in the dark. Cell surface proteins were detected using a twostep method. Cells were collected and washed twice with PBS before being stained. Cells were incubated with primary antibodies respectively including mouse antihuman CRT antibody TO-11 [36] and human antihuman HSP90 antibody (W9 which recognizes an epitope of an isoform of HSP90, GRP94 selectively expressed on cancer cell surface [37]) at $4{ }^{\circ} \mathrm{C}$ for $1 \mathrm{~h}$, then incubated respectively with Allophycocyanin (APC)

Table 1 ICD hall markers showed in BCSCs vs non-BCSCs after irradiation

\begin{tabular}{|c|c|c|c|c|c|c|c|c|}
\hline & \multicolumn{4}{|c|}{ MDA-MB-231 } & \multicolumn{4}{|c|}{ UACC-812 } \\
\hline & \multicolumn{2}{|c|}{$\mathrm{ALDH}^{\text {bright }}$ as marker } & \multicolumn{2}{|c|}{ CD44+/CD24-/ESA+ as marker } & \multicolumn{2}{|c|}{ ALDH bright as marker } & \multicolumn{2}{|c|}{ CD44+/CD24-/ESA+ as marker } \\
\hline & $8 \mathrm{~Gy}$ & $12 \mathrm{~Gy}$ & $8 \mathrm{~Gy}$ & $12 \mathrm{~Gy}$ & $8 \mathrm{~Gy}$ & $12 \mathrm{~Gy}$ & $8 \mathrm{~Gy}$ & $12 \mathrm{~Gy}$ \\
\hline Apoptosis & $\downarrow \downarrow$ & $\downarrow \downarrow$ & $\downarrow \downarrow$ & $\downarrow$ & $\downarrow \downarrow$ & $\downarrow \downarrow$ & $\downarrow \downarrow$ & $\downarrow$ \\
\hline CRT & $\downarrow$ & - & $\downarrow$ & - & $\downarrow$ & $\downarrow$ & $\downarrow$ & $\downarrow$ \\
\hline HSP90 & $\downarrow$ & - & - & - & - & - & - & $\downarrow$ \\
\hline ATP & $\uparrow$ & $\uparrow$ & $\uparrow$ & $\uparrow \uparrow$ & - & $\uparrow$ & - & $\uparrow$ \\
\hline HMGB1 & $\downarrow \downarrow$ & $\downarrow \downarrow$ & $\downarrow \downarrow$ & $\downarrow \downarrow$ & $\downarrow \downarrow$ & $\downarrow \downarrow$ & $\downarrow \downarrow$ & $\downarrow \downarrow$ \\
\hline
\end{tabular}

$\uparrow$ (down) and $\downarrow$ (up). $\mathrm{P}<0.05, \uparrow \uparrow$ and $\downarrow \downarrow \mathrm{P}<0.01$, - not significant (BCSCs vs non-BCSCs) 
A. Apoptotic effect
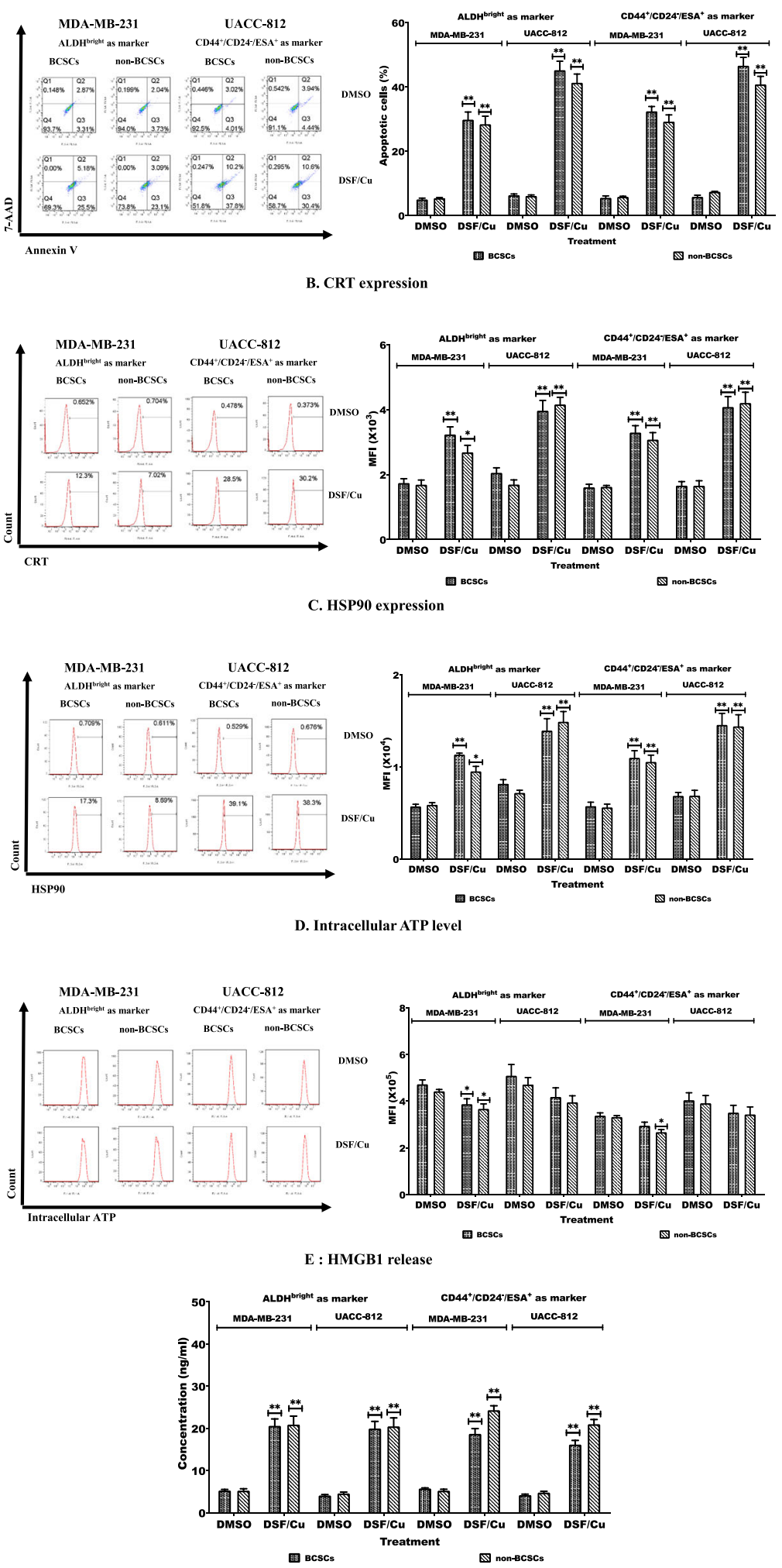

Fig. 3 (See legend on next page.) 
(See figure on previous page.)

Fig. $3 \mathrm{DSF} / \mathrm{Cu}$ induced a similar extent of IDC in both BCSCs and non-BCSCs. Sorted cells were treated with (0.15/1 $\mu \mathrm{M}) \mathrm{DSF} / \mathrm{Cu}$ for $24 \mathrm{~h}$ and then cells and supernatants were analyzed for ICD. (a) Apoptotic cells were quantitated (left panel). Percentage of apoptotic cells are indicated (right panel). (b) Percentages of cells expressing CRT (left panel) and their mean MFI values are indicated (right panel). (c) Percentages of cells expressing HSP90 (left panel) and their MFI values (right panel). (d) Levels of intracellular ATP were measured (left panel) and their MFI values are shown (right panel). (e) Concentrations of HMGB1 release were determined in supernatants. ${ }^{*}$ indicates $p<0.05$, **indicates $p<0.01$ (DSF/CU treated vs DMSO treated cells)

AffiniPure F $\left(\mathrm{ab}^{\prime}\right)_{2}$ Fragment Goat Anti-Mouse IgG $(\mathrm{H}+\mathrm{L})$ or R-Phycoerythrin AffiniPure $\mathrm{F}\left(\mathrm{ab}^{\prime}\right)_{2}$ Fragment Goat Anti-Human IgG, Fcy fragment from Jackson ImmunoResearch Laboratories, Inc. USA. Isotype-matched IgG antibodies were used as controls. The following PE-conjugated rabbit mAbs (1:50) from Cell Signaling were used: mAb for CRT (D3E6) (for Fig. 4c 24h post IR staining only), mAb for HSP90 (C45G5) (for Fig. 4d 24h post IR staining only) and $\mathrm{mAb}$ IgG Isotype Control (DA1E) as a specificity control for both rabbit anti- CRT or -HSP90 mAbs (Fig. 4c, d). Each sample was analyzed by BD Accuri ${ }^{\mathrm{mu}}$ C6 Flow Cytometer (BD Bioscience) and FlowJo software.

\section{Western blot analysis}

Cells were plated in 6-well plates at a density of $5 \times 10^{4}$ cells in $2 \mathrm{~mL}$ of the culture medium and grown overnight. The cells were treated with $0.15 / 1 \mu \mathrm{M}$ DSF/Cu for $24 \mathrm{~h}$, then irradiated with $12 \mathrm{~Gy}$ and cultured for additional $24 \mathrm{~h}$ before being lyzed. The cell lysates were used for detection of cleaved PARP by western blot using rabbit mAb ((Asp214) (D64E10),1:1000, Cell Signaling), and $\beta$-actin rabbit mAb ((13E5), 1:1000, Cell Signaling) for a protein loading control, as described [34].

\section{Detection of intracellular and extracellular ATP}

Intracellular ATP was stained with the ATP-sensitive fluorochrome quinacrine [38]. Cells $\left(5 \times 10^{4}\right)$ were incubated with $10 \mu \mathrm{M}$ quinacrine dihydrochloride (Sigma) in $100 \mu \mathrm{L}$ PBS at $37^{\circ} \mathrm{C}$ for $1 \mathrm{~h}$. Then the cells were washed 4 time with PBS and resuspended in $100 \mu \mathrm{L}$ for flow analysis. Fluorescence was detected by flow cytometer at $510-530 \mathrm{~nm}$ with excitation at $488 \mathrm{~nm}$ [39]. A decreased level of intracellular ATP reflects an increase of extracellular ATP release. To confirm it, we measured quantitatively extracellular released ATP by testing some of the collected cell culture supernatants (by centrifugation at $2000 \mathrm{rpm}, 10 \mathrm{~min}, 4{ }^{\circ} \mathrm{C}$, MICROCL 17R, Thermo Scientific) with ATP Bioluminescence Assay Kit HS II (Roche, Mannheim, Germany) per manufacturer's instructions, with the Synergy 2 Multi-Detection Microplate Reader (BioTek, Winooski, USA).

\section{Quantitation of extracellular HMGB1}

The culture supernatants of cells were collected for detection of HMGB1 release at the same time when the cells were harvested for flow analysis. The concentrations of HMGB1 in undiluted supernatants were measured using
HMGB1 ELISA Kit according to the manufacturer's instructions (ABIN511375, IBL America, MN, USA).

\section{Statistical analysis}

Data were analyzed by SPSS version 19.0 (SPSS Inc., Chicago, IL, USA) and determined by one-way ANOVA. The results were obtained in 2-3 independent experiments. Differences between groups were considered significant when $p<0.05$.

\section{Results}

Identification and flow sorting of BCSCs from breast cancer cell lines

$\mathrm{ALDH}^{\text {bright }}$ and $\mathrm{CD} 44^{+} / \mathrm{CD} 24^{-} / \mathrm{ESA}^{+}$tumor cells, previously shown to have BCSC properties, were isolated from human MDA-MB-231 and UACC-812 breast cancer cell lines by FACS (Fig. 1a). BCSCs in MDA-MD-231 cells consisted of $5.2 \% \mathrm{ALDH}^{\text {bright }}$ and $21.6 \% \mathrm{CD}^{-} 4^{+} / \mathrm{CD} 24^{-} /$ $\mathrm{ESA}^{+}$cells (sorted cells were $85.3 \% \mathrm{CD}^{+} 4^{+} / \mathrm{CD} 24^{-}$of which $25.4 \%$ were $\mathrm{ESA}^{+}$, therefore \% of $\mathrm{CD}_{4} 4^{+} / \mathrm{CD} 24^{-} /$ $\mathrm{ESA}^{+}$cells was $85.3 \%$ x $25.4 \%=21.6 \%$ ). The UACC-812 cell line contained $4.9 \% \mathrm{ALDH}^{\text {bright }}$ and $23.1 \% \mathrm{CD}^{+} 4^{+} /$ CD24 / ESA $^{+}$cells (sorted cells were $83.6 \% \mathrm{CD}^{2} 4^{+} / \mathrm{CD} 24^{-}$ of which $27.6 \%$ were $\mathrm{ESA}^{+}$, therefore $\%$ of $\mathrm{CD}_{4} 4^{+} / \mathrm{CD} 24^{-} /$ $\mathrm{ESA}^{+}$cells was $83.6 \%$ x $\left.27.6 \%=23.1 \%\right) . \mathrm{ALDH}^{\mathrm{dim}}$ and ESA $^{-}$cells in MDA-MB-231 and UACC-812 cell lines, which were considered as non-BCSCs, were also sorted from these cell lines. In addition, we did qRT-PCR on sorted BCSCs vs non-BCSCs for mRNA expression of ALDH1A1 which is one of the main contributors to ALDH activity detected by ALDEFLUOR [40]. The data were consistent with ALDEFLUOR assay by which we identified and sorted ALDH ${ }^{\text {bright }} / \mathrm{ALDH}^{\mathrm{dim}}$ cells, i.e., ALDH ${ }^{\text {bright }}$ cells expressed higher levels (18-25 fold increase) of ALDH1A1 mRNA than that in $\mathrm{ALDH}^{\mathrm{dim}}$ cells (Fig. 1b). The mammosphere formation abilities of the sorted cell populations isolated from both cell lines were determined. The results indicate that BCSCs sorted from the two human breast cancer cell lines had a more pronounced ability to form mammospheres, a key functional property of BCSCs, than the non-BCSCs sorted from them (Fig. 1c).

\section{IR triggered a lower level of ICD in BCSCs than in non- BCSCs}

Since it is generally considered that BCSCs existing in solid tumors contribute to RT resistance $[6,41,42]$, the 


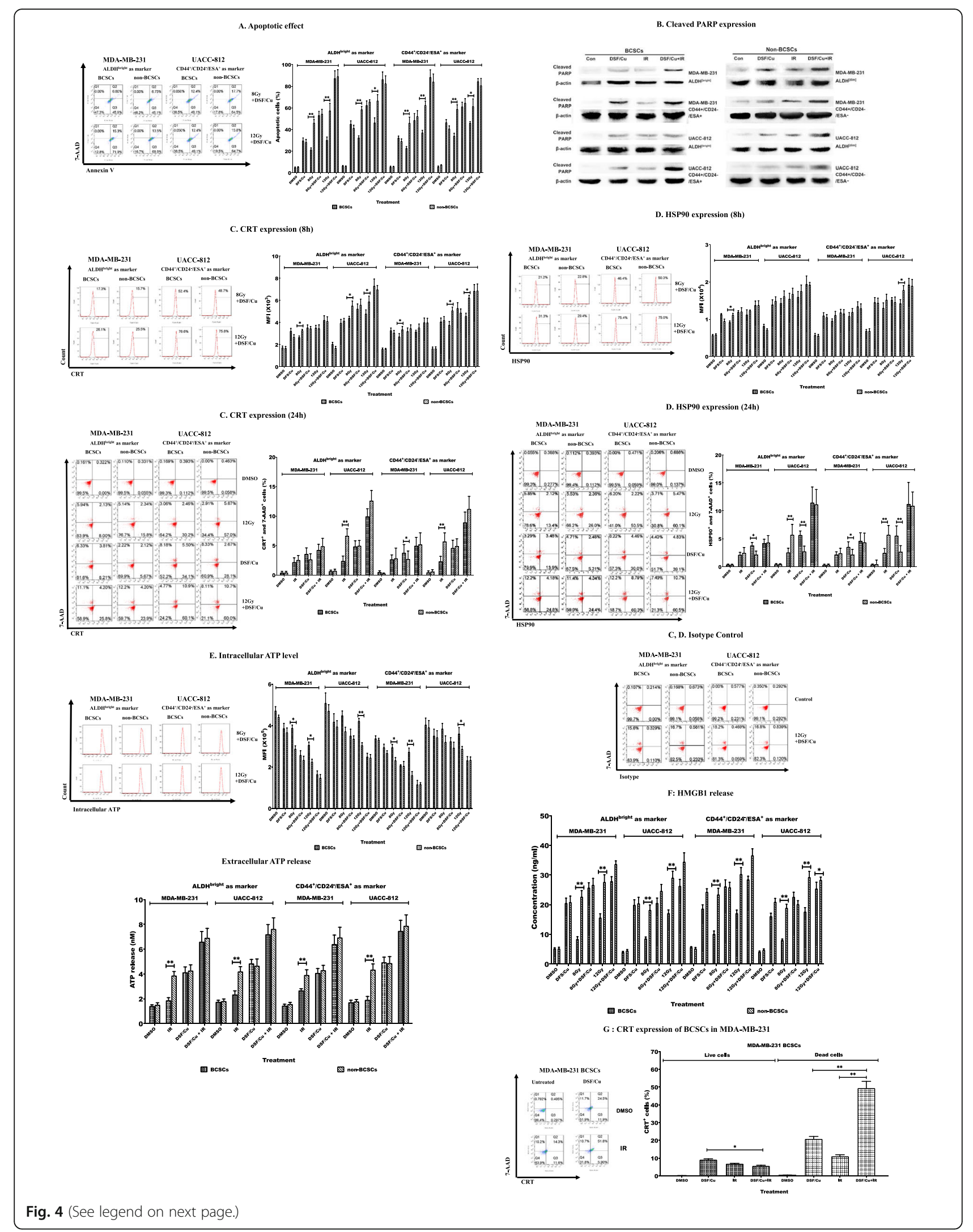


(See figure on previous page.)

Fig. 4 DSF/Cu rendered BCSCs as sensitive as non-BCSCs to IR-induced ICD. Sorted sells were pretreated with DSF/Cu $(0.15 / 1 \mu \mathrm{M})$ for $24 \mathrm{~h}$, then DSF/Cu containing medium was removed and replaced with fresh culture medium and then irradiated at 8 or 12 Gy and cultured. The cells and/or culture supernatants were collected at indicated times post IR and used for analyses of ICD. (a) Apoptotic cells were quantitated $24 \mathrm{~h}$ post-IR (left panel). Percentages of apoptotic cells are indicated (right panel). (b) Cleaved PARP, an indicator of apoptosis, was detected in both BCSCs and nonBCSCs treated by DSF/Cu and IR. (c) Percentages of cells expressing CRT were detected $8 \mathrm{~h}$ post IR (left panel) and their mean fluorescence intensity (MFI) values are shown (right panel); Percentages of $7 A A D^{+}$cells expressing CRT were detected $24 \mathrm{~h}$ post IR (left panel) and means $\pm S D$ of $7 A A D^{+} C R T^{+}$ cells (\%) are shown (right panel). (d) Percentages of cells expressing HSP90 were detected $8 \mathrm{~h}$ post IR (left panel) and their MFI values are shown (right panel); Percentages of 7AAD ${ }^{+}$cells expressing HSP90 were detected $24 \mathrm{~h}$ post IR (left panel) and means \pm SD of 7AAD $\mathrm{HSP}^{+}$cells (\%) are shown (right panel), PE-conjugated rabbit isotype control mAb was simultaneously stained cells with PE-conjugated rabbit mAb for CRT and HSP90 $24 \mathrm{~h}$ post IR-negative control results shown as C, D isotype control. (e) Levels of intracellular ATP were measured $1 \mathrm{~h}$ post-IR (left panel) and their MFI values are shown (right panel); Levels of extracellular ATP release were measured $24 \mathrm{~h}$ post-IR. (g) Concentrations of HMGB1 release were determined in supernatants collected at $24 \mathrm{~h}$ post-IR. (g) CRT expression was quantitated in dead (7-AAD ${ }^{+}$) and live (7-AAD-) MDA-MB-231 BCSCs. *indicates $p<0.05$, **indicates $p<0.01$

conditions under which IR can induce ICD of BCSC was investigated using sorted $\mathrm{ALDH}^{\text {bright }}$ and $\mathrm{CD} 44^{+} / \mathrm{CD} 24^{-} /$ $\mathrm{ESA}^{+} \mathrm{BCSC}$ exposed to 8 or $12 \mathrm{~Gy}$. These cells were then monitored for apoptosis and the above-mentioned parameters of IDC-mediating DAMPs. Apoptosis was induced by $8 \mathrm{~Gy}$ and $12 \mathrm{~Gy}$ IR in BCSCs and non-BCSCs of both breast cancer cell lines as showed in Fig. 2a. IR (8Gy) induced apoptosis in both sorted BCSC populations, which ranged from $21.5 \pm 1.5 \%$ to $34.1 \pm 2.4 \%$, while the range of apoptotic cells in non-BCSCs was higher at $46.1 \pm 5.4 \%$ to $58.9 \pm 4.0$. The percentages of apoptotic cells following IR (12 Gy) ranged from $30.3 \pm 2.8 \%$ to $46.4 \pm 4.4 \%$ in BCSCs and $57.5 \pm 6.7 \%$ to $66.7 \pm 5.5 \%$ in non-BCSCs. Therefore, regardless of whether $8 \mathrm{~Gy}$ or $12 \mathrm{~Gy}$ was employed, the differences of the lower rates of apoptosis of BCSCs compared to that of non-BCSCs were significant $(p<0.05$ or $p<0.01$ ) (Fig. 2a).

In contrast to apoptosis, the index of RT-induced ICD relative to DAMPs varied with the breast cancer cell line tested, defined BCSC phenotype and IR dosage. CRT expression was significantly higher on the surface of the sorted non-BCSCs compared to BCSCs of UACC-812 cell line, regardless of whether they were sorted as $\mathrm{ALDH}^{\text {bright }}$ or $\mathrm{CD} 44^{+} / \mathrm{CD} 24^{-} / \mathrm{ESA}^{+} \mathrm{BCSC}$ and whether treated with $8 \mathrm{~Gy}$ or $12 \mathrm{~Gy}$ IR $(p<0.05$ or $p<0.01)$. In regard to MDA-MB-231 cells, significant differences between the CRT expression of non-BCSCs and either sorted BCSC phenotype were noted at 8 Gy IR $(p<0.05)$ but not 12Gy (Fig. 2b). Regarding HSP90 cell surface expression, the findings showed more diversity. MDA-MB231 ALDH $^{\text {bright }}$ BCSCs showed a significantly lower HSP90 expression than non-BCSCs at 8 Gy but not 12 Gy, whereas UACC-812 ALDH ${ }^{\text {bright }}$ BCSCs showed no differences regardless of IR dosage. However, UACC-812 $\mathrm{CD}_{4} 4^{+} / \mathrm{CD} 24^{-} / \mathrm{ESA}^{+}$BCSC showed a difference in HSP90 expression at $12 \mathrm{~Gy}$ but not 8 Gy IR $(p<0.05)$, with a trend of more increasing HSP90 expression in non-BCSCs than BCSCs in responding to IR at $8 \mathrm{~Gy}$ or 12 Gy being noticeable (Fig. 2c). The third ICD parameter monitored was intracellular ATP, which decreases with ICD. As shown in Fig. 2d, intracellular ATP levels were significantly decreased, in sorted non-BCSCs compared with sorted $\mathrm{ALDH}{ }^{\text {bright }}$ or $\mathrm{CD} 44^{+} / \mathrm{CD} 24^{-} / \mathrm{ESA}^{+}$ BCSCs obtained from MDA-MB-231 cells after 8 Gy or 12 Gy IR $(p<0.05$ or $p<0.01)$, but there was a difference in UACC-812-derived non-BCSC populations compared to both types of sorted BCSC populations only after 12 Gy IR $(p<0.05)$. Nevertheless, a trend of more decreased intracellular ATP in non-BCSCs than BCSCs in responding to IR at $8 \mathrm{~Gy}$ or $12 \mathrm{~Gy}$ was noted.

At either $8 \mathrm{~Gy}$ or $12 \mathrm{~Gy}$ IR, the fourth ICD parameter monitored, HMGB1 release, showed significant differences between the two types of sorted BCSC phenotypes and non-BCSCs derived from both cell lines $(p<0.05$ or $p<0.01$ ) (Fig. 2e).

These data demonstrated that IR induced less apoptosis, lower levels of cell surface expression of CRT and HSP90 and lower levels of ATP and HMGB1 release in sorted BCSCs of either phenotype than in sorted nonBCSCs, which indicates that IR induced lower levels of ICD in BCSCs than in non-BCSCs. A summary of these findings is shown in Table 1.

\section{DSF/Cu induced a similar extent of IDC in both BCSCs and non-BCSCs}

CSCs are resistant to most standard radiotherapies as well as chemotherapies. Our previous studies revealed that $\mathrm{DSF} / \mathrm{Cu}$ can preferentially eliminate BCSCs and pancreatic CSCs in vitro and in vivo in the context of IR or chemoradiation $[6,17]$. However, the ability of DSF/Cu in the induction of ICD of BCSC and non-BCSC populations has not been investigated to date. Therefore, the effect of $\mathrm{DSF} / \mathrm{Cu}$ and the control diluent vehicle, DMSO, on ICD of both sorted phenotype BCSC populations as well as non-BCSCs was initially assessed. Apoptosis was detected in all four cell populations derived from MDAMB-231 and UACC-812 cells, as showed in Fig. 3a. DSF/ $\mathrm{Cu}$ induced apoptosis in both sorted BCSCs and nonBCSCs compared to DMSO $(p<0.05)$, and there were no obvious differences on apoptotic ratios in sorted 


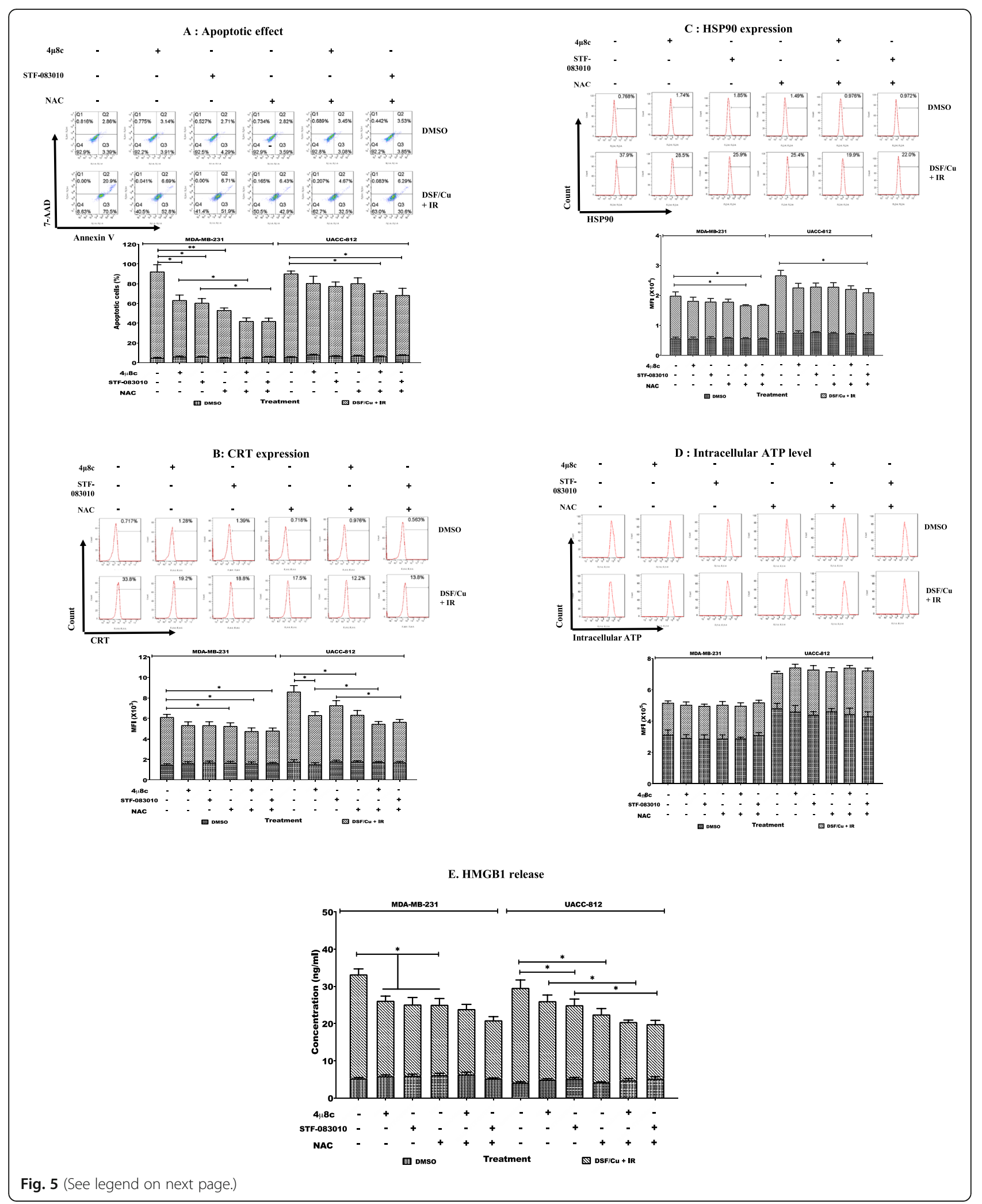


(See figure on previous page.)

Fig. 5 Blockade of ROS and IRE1a/XBP1s axis inhibited ICD induced by DSF/Cu and irradiation in BCSCs. Sorted BCSCs were pretreated with $10 \mu \mathrm{M} 4 \mathrm{U} 8 \mathrm{c}, 10 \mu \mathrm{M}$ STF-083010 or $10 \mathrm{mM}$ NAC for $1 \mathrm{~h}$. The inhibitor(s) containing medium was replaced with fresh culture medium with DSF/Cu $(0.15 / 1 \mu \mathrm{M})$ and cultured for $24 \mathrm{~h}$. Then DSF/Cu containing medium was removed and replaced with fresh culture medium and then irradiated at $12 \mathrm{~Gy}$ and cultured. The cells and/or culture supernatants were collected at indicated times post IR and used for analyses of ICD. (a) Apoptotic cells were quantitated $24 \mathrm{~h}$ post-IR (top panel). Percentages of apoptotic cells are indicated (bottom panel). (b) Percentages of cells expressing CRT were detected $8 \mathrm{~h}$ post IR (top panel) and their mean fluorescence intensity (MFI) values are shown (bottom panel). (c)

Percentages of cells expressing HSP90 were detected $8 \mathrm{~h}$ post IR (top panel) and their MFI values are shown (bottom panel). (d) Levels of intracellular ATP were measured $1 \mathrm{~h}$ post-IR (top panel) and their MFI values are shown (bottom panel). (e) Concentrations of HMGB1 release were determined in supernatants collected at $24 \mathrm{~h}$ post-IR. *indicates $p<0.05$, **indicates $p<0.01$. These data demonstrate that blocking ROS generation and IRE1a/XBP1s signaling pathway partially abolished elevated ICD of BCSCs by IR and DSF/Cu and implies that both pathways are involved in the enhanced immunogenic apoptosis of BCSCs induced by this combinatorial approach

BCSCs and non-BCSCs isolated from MDA-MB-231 and UACC-812 cell lines. DSF/Cu treatment increased CRT (Fig. 3b) and HSP90 (Fig. 3c) expression on the surface of all four cell populations analyzed $(p<0.05$ or $p<0.01)$. Intracellular ATP levels were decreased in the non-BCSCs and two phenotypic distinct BCSCs sorted from MDA-MB-231 cell line $(p<0.05$ or $p<0.01)$ and a trend of decreased intracellular ATP in BCSCs and nonBCSCs sorted from UACC-812 cell line was noted (Fig. 3d). HMGB1 release was significant increased in all the DSF/Cu-treated sorted cells $(p<0.01)$ (Fig. 3e).

\section{$\mathrm{DSF} / \mathrm{Cu}$ rendered $\mathrm{BCSC}$ as sensitive as non-BCSCs to IR- induced ICD}

To determine whether DSF/Cu can enhance the sensitivity of BCSCs to IR-induced ICD, BCSCs and non-BCSCs sorted from MDA-MB-231 and UACC-812 cell lines were irradiated following $\mathrm{DSF} / \mathrm{Cu}$ treatment and monitored for apoptosis and the four parameters of ICDmediating DAMPs previously detailed. DSF/Cu in combination with IR ( $8 \mathrm{~Gy}$ or $12 \mathrm{~Gy}$ ) resulted in increased ICD including apoptosis, CRT and HSP90 expression, and ATP and HMGB1 release in all four sorted cell populations (Fig. 4a-g).

The significant differences in apoptosis between BCSCs and non-BCSCs in responding to IR only (8 or 12 Gy) previously noted disappeared when they were treated with DSF/Cu prior to IR. In other words, DSF/ $\mathrm{Cu}$ made BCSCs equally sensitive to IR-induced apoptosis as non-BCSCs (Fig. 4a). The apoptosis of cells was confirmed by detecting cleaved PARP, an indicator of apoptosis, in western blotting (Fig. 4b) In addition, comparing to 8 or 12 Gy IR alone, prior treatment of the two types of BCSC populations sorted from MDA-MB-231 and UACC-812 cell line with $\mathrm{DSF} / \mathrm{Cu}$ at 8 or $24 \mathrm{~h}$ showed increased cell surface CRT expression compared to sorted non-BCSCs from these cell lines (Fig. 4c); a similar finding in HSP90 cell surface expression was obtained in $\mathrm{ALDH}^{\text {bright }} \mathrm{BCSC}$ from MDA-MB-231 cell line and $\mathrm{CD}_{4} 4^{+} / \mathrm{CD} 24^{-} / \mathrm{ESA}^{+}$BCSCs from UCAA-812 cell line to 8 and 12 Gy IR, respectively. The staining was specific as isotype controls was negative in dead/ dying cells (Fig. 4c, d). Moreover, BCSCs defined either by $\mathrm{ALDH}^{\text {bright }}$ or $\mathrm{CD} 44^{+} / \mathrm{CD} 24^{-} / \mathrm{ESA}^{+}$had decreased intracellular ATP, reflecting increased extracellular ATP and increased ATP release in cell supernatants to 8 or 12 Gy IR (Fig. 4e); lastly, all four BCSC populations had increased HMGB1 release to 8 and 12 Gy IR (Fig. 4f).

Furthermore, to determine whether CRT is indeed expressed by $\mathrm{DSF} / \mathrm{Cu}$ and IR-induced $7-\mathrm{AAD}^{+}$dying cells, ALDH ${ }^{\text {bright }}$ BCSCs sorted from MDA-MB-231cell line were analyzed with $7-\mathrm{AAD}^{+}$dying and $7-\mathrm{AAD}^{-}$live cells for CRT expression. Following treatment with DSF/ $\mathrm{Cu}$ and IR, $49.4 \pm 3.8 \%$ were $7-\mathrm{AAD}^{+} \mathrm{CRT}^{+}$, which is significantly higher than that in either $\mathrm{DSF} / \mathrm{Cu}$ or IR treated ALDH ${ }^{\text {bright }}$ BCSCs $(p<0.001)$ (Fig. 4g). On the other hand, only $5.6 \pm 0.4 \%$ of $7-\mathrm{AAD}^{-}$cells were $\mathrm{CRT}^{+}$ (Fig. 4g). The data indicate that combination of DSF/Cu and IR at the indicated doses induced ICD in $~ 50 \%$ of BCSCs compared to $\sim 10 \%$ of that in BCSCs treated by IR alone. These data suggested that $\mathrm{DSF} / \mathrm{Cu}$ rendered IR-resistant BCSCs as sensitive as non-BCSC to IRinduced ICD.

\section{ROS generation and IRE1a/XBP1 axis are partially responsible for increased IR-induced ICD of BCSCs by DSF/Cu}

It is known that DSF/Cu generates ROS [15]. Our recent work demonstrated DSF/Cu induces strong ER stress through activation of the IRE1 $\alpha / \mathrm{XBP} 1$ axis of the unfolded protein response (UPR) [16]. These findings, especially the latter, led to the hypothesis that $\mathrm{DSF} / \mathrm{Cu}$ could induce IDC since ER stress and ROS production are key players of the intracellular signaling pathways that govern ICD [27]. To this end, the functional importance of ROS in the enhanced ICD of sorted BCSCs sensitized to IR by DSF/ $\mathrm{Cu}$ was examined by monitoring apoptosis and the four DAMPs associated with ICD in BCSCs pretreated with the ROS scavenger, $\mathrm{N}$-acetyl cysteine (NAC) prior to $\mathrm{DSF} / \mathrm{Cu}$ exposure and IR. Concurrently, the role of the IRE1 $\alpha / \mathrm{XBP} 1$ axis in ICD of BCSCs induced by DSF/Cu and IR was examined. When BCSCs were pretreated with NAC or the IRE1 $\alpha /$ XBP1 pathway inhibitors STF-083010 or $4 \mu 8 \mathrm{c}$, the elevated apoptosis induced by pretreatment 
with DSF/Cu followed by IR $12 \mathrm{~Gy}$ for $24 \mathrm{~h}$ was suppressed $(p<0.05$ or $p<0.01$ (Fig. 5a). Moreover, combinations of NAC with either STF-083010 or $4 \mu 8 \mathrm{c}$ showed more pronounced inhibition of DSF/Cu and IR induced apoptosis of BCSCs compared to either single inhibitor treatment of the MDA-MB-231 cell line $(p<0.05)$ (Fig. 5a). Apoptosis of UACC-812 BCSCs was suppressed only by combinative pretreatment with STF-083010 and NAC or $4 \mu 8 \mathrm{c}$ and NAC $(p<0.05)$ (Fig. 5a). CRT surface expression of MDA-MB-231 BCSCs was suppressed when cells were pretreated with NAC alone or NAC combined with STF083010 or $4 \mu 8 \mathrm{c}(p<0.05)$ (Fig. 5b). A similar inhibition pattern of CRT surface expression on UACC-812 BCSCs was evidenced except $4 \mu 8 \mathrm{c}$ inhibited CRT expression as a single agent $(p<0.05)$ (Fig. $5 \mathrm{~b})$. For all the BCSCs examined, only the combination of STF-083010 and NAC or $4 \mu 8 \mathrm{c}$ and NAC showed suppressive function on HSP90 surface expression $(p<0.05)$ (Fig. 5c). However, intracellular ATP levels showed no changes when BCSCs were pretreated with any single inhibitor or inhibitor combinations (Fig. 5d), whereas all the agents individually suppressed HMGB1 release in all the BCSCs populations studied $(p<$ 0.05) (Fig. 5e) and combination of NAC with either STF083010 or $4 \mu 8 \mathrm{c}$ showed stronger suppression of HMGB1 release compared to single inhibitor pretreatment in UCAA-812 cell line $(p<0.05)$ (Fig. 5e).

\section{Discussion}

BCSCs are resistant to chemotherapy and radiation $[2,6$, 41,43 ] and recent studies demonstrated that BCSCs escape from innate and adaptive immune responses, which suggests that BCSCs are resistant to immunotherapy as well [44-48]. These findings underscore the importance of developing novel approaches that make BCSCs as sensitive as non-BCSCs to conventional therapies and immunotherapy in order to develop successful and curative treatments for breast cancer patients. It is known that IR can trigger ICD of breast and other cancer cells [23], but clinically, RT is often inadequate in generating sufficient immuno-stmularoty signals to optimally activate innate and adaptive immune responses. Thus, IR may induce a level of ICD in BCSCs that is insufficient to generate an effective anti-tumor immune response. We hypothesized that $\mathrm{DSF} / \mathrm{Cu}$ is an ideal agent to induce ICD for the following reasons: i) it preferentially targets CSCs [17], ii) induces ROS [15], and iii) induces ER stress and autophagic apoptosis [16]. Both ER stress and ROS are key players of intracellular signaling pathways that govern ICD [27], and in addition, autophagy can trigger ICD [26]. Therefore, we investigated the ability of DSF/Cu to induce IDC of BCSCs and non-BCSCs and the possibility for $\mathrm{DSF} / \mathrm{Cu}$ to render radiation-resistant $\mathrm{BCSCs}$ as sensitive as radiation-sensitive-non-BCSCs.
Compared to non-BCSCs, IR at tested single doses (8 and $12 \mathrm{~Gy}$ ) only induced a much lower level of ICD in BCSCs than non-BCSCs. The BCSCs were identified in both MDA-MB-231 (triple negative) and UACC-812 (ER ${ }^{+}, \mathrm{HER}^{\mathrm{amp}}$ ) cell lines [49] by either high ALDH activity or expression of the cell surface phenotype $\mathrm{CD} 44^{+} / \mathrm{CD} 24^{-} / \mathrm{ESA}^{+}$. As expected, DSF $/ \mathrm{Cu}$ was able to induce a similar extent of ICD in both BCSCs and non-BCSCs. Pretreatment with a low dose of DSF $(0.15 \mu \mathrm{M})$ and a physiological level of $\mathrm{CuCl}_{2}(1$ $\mu \mathrm{M})$ rendered IR-resistant BCSCs as sensitive as nonBCSC to IR-induced ICD. All the IDC parameters studied, the percentage of apoptotic cells, CRT and HSP90 cell surface expression, and release of HMGB1 and ATP in BCSCs were increased by DSF/Cu and IR treatment. ROS and IRE1 $\alpha / \mathrm{XBP} 1$ axis also appear to be involved in DSF/Cu and IR-induced ICD of BCSCs, since ROS scavenger and IRE1 $\alpha / \mathrm{XBP} 1$ pathway inhibitors combined partially blocked apoptosis, CRT and HSP90 cell surface expression and HMGB1 release, but not ATP levels in these treated cells. One can conclude, therefore, that in addition to enhanced ROS production and IRE1 $\alpha /$ XBP1 axis activation, DSF/Cu and IR-induced ICD of BCSCs should involve other mechanisms.

To our knowledge, our study demonstrates, for the first time, that IR triggered a lower level of ICD in BCSCs than in non-BCSCs using the in vitro characteristic parameters of apoptosis and ICD-mediating DAMPs. Consistent with the fact that BCSCs are IR-resistant, $\mathrm{BCSCs}$ are also resistant to IR-induced ICD. Therefore, by taking advantage of using DSF/Cu pretreatment, we could induce the same extent of ICD in both BCSCs and non-BCSCs by IR. This is the first study aiming at induction of ICD in radiation-resistant BCSCs by repurposing DSF. The results derived from this in vitro-based study has prompted our laboratory to initiate an ongoing in vivo-based study using preclinical tumor models to investigate the potential of IR and DSF/Cu-induced ICD of BCSCs and non-BCSCs as a potent vaccine to activate the host's immune system to generate robust and durable anti-tumor immune responses against primary breast tumors as well as distant metastasis. Additionally, our finding is fundamental to the opening of a new research area aimed at exploring the possibility of using BCSCs as an immunogen in breast cancer vaccines to induce effective systemic immune responses against not only differentiated/ differentiating breast cancer cells but also BCSCs, the root cause of breast cancer formation, progression and metastasis.

\section{Conclusions}

In this study, we identified that BCSCs are resistant to IR-induced ICD. However, we found that DSF/Cu rendered IR-resistant BCSCs as sensitive as non-BCSCs to 
IR-induced ICD. This may due partially to DSF/Cu induced ROS production and IRE1 $\alpha / \mathrm{XBP} 1$ axis activation. Our finding is fundamental to the opening of a new research area aimed at exploring the possibility of using BCSCs as the immunogen in a IR-based breast cancer vaccine.

\section{Abbreviations}

ALDH: aldehyde dehydrogenase; APCs: Antigen presenting cells; ATCC: American Type Culture Collection; ATP: Adenosine triphosphate; BCSCs: Breast cancer stem cells; CRT: Calreticulin; CSCs: Cancer stem cells; DAMPs: Damage-associated molecular pattern molecules; deDTC: diethyldithiocarbamate; DSF/Cu: Disulfiram/cooper; ER: endoplasmic reticulum; Gy: Gray; HMGB1: High mobility group protein B1; HSPs: Heat shock proteins; ICD: Immunogenic cell death; IR: Irradiation; IRE1a: Inositol requiring-enzyme 1 alpha; ROS: Reactive oxygen species; RT: Radiation therapy; XBP1: X-box-binding protein 1; XBP1s: Spliced/active form of XBP1

\section{Acknowledgements}

Not applicable.

\section{Ethical approval and consent to participate}

Not applicable.

\section{Conflict of interest}

The authors declare that they have no competing financial interests.

\section{Availability of supporting data and materials}

The original data and cell lines that supporting the conclusion of this article are available upon request.

\section{Author contribution}

Conception and design: XW. Development of methodology: TS. Acquisition of data: TS. Analysis and interpretation of data: TS, WY, XW, ST, LH, AD. Writing, review and/or revision of the manuscript: XW, TS, AD. Study supervision: XW. Technical advice: WG, GZ, EW, ZL, PH. Conceptual advice: SF. All authors read and approved the final manuscript.

\section{Authors' information}

As shown in the page.

\section{Funding}

This work was supported by grants R01CA226981-01A1 (X.W.), Massachusetts General Hospital ECOR Formulaic Bridge Funding (X.W.) and W81XWH-16-10500 Department of Defense Breakthrough Award Level 2 (S.F.).

\section{Consent for publication}

Consented by all authors.

\section{Competing interests}

None.

\section{Author details}

'Division of Surgical Oncology, Department of Surgery, Massachusetts General Hospital, Harvard Medical School, Boston, USA. ${ }^{2}$ Neurosurgery and Brain and Nerve Research Laboratory, The First Affiliated Hospital of Soochow University, Suzhou, Jiangsu, China. ${ }^{3}$ John B. Little Center for Radiation Sciences, Harvard T.H. Chan School of Public Health, Boston, USA. ${ }^{4}$ State Key Laboratory of Radiation Medicine and Protection, School of Radiation Medicine and Protection and Collaborative Innovation Center of Radiation Medicine of Jiangsu Higher Education Institutions, Soochow University, Suzhou, China. ${ }^{5}$ Department of Orthopaedic Surgery,

Massachusetts General Hospital, Harvard Medical School, Boston, USA.

Received: 6 July 2019 Accepted: 27 December 2019

Published online: 05 March 2020

\section{References}

1. O'Brien CA, Kreso A, Dick JE. Cancer stem cells in solid tumors: an overview. Semin Radiat Oncol. 2009;19:71-7.
2. McDermott SP, Wicha MS. Targeting breast cancer stem cells. Mol Oncol. 2010:4:404-19.

3. Oskarsson T, Batlle E, Massague J. Metastatic stem cells: sources, niches, and vital pathways. Cell Stem Cell. 2014;14:306-21.

4. Lawson DA, Bhakta NR, Kessenbrock K, Prummel KD, Yu Y, Takai K, Zhou A, Eyob H, Balakrishnan S, Wang CY, et al. Single-cell analysis reveals a stem-cell program in human metastatic breast cancer cells. Nature. 2015;526:131-5.

5. Ginestier C, Hur MH, Charafe-Jauffret E, Monville F, Dutcher J, Brown M, Jacquemier J, Viens P, Kleer CG, Liu S, et al. ALDH1 is a marker of normal. and malignant human mammary stem cells and a predictor of poor clinical outcome. Cell Stem Cell. 2007;1:555-67.

6. Wang Y, Li W, Patel SS, Cong J, Zhang N, Sabbatino F, Liu X, Qi Y, Huang P, Lee $\mathrm{H}$, et al. Blocking the formation of radiation-induced breast cancer stem cells. Oncotarget. 2014;5:3743-55.

7. Visus C, Wang Y, Lozano-Leon A, Ferris RL, Silver S, Szczepanski MJ, Brand RE, Ferrone CR, Whiteside TL, Ferrone S, et al. Targeting ALDH (bright) human carcinoma-initiating cells with ALDH1A1-specific CD8(+) T cells. Clin Cancer Res. 2011:17:6174-84.

8. Eneanya DI, Bianchine JR, Duran DO, Andresen BD. The actions of metabolic fate of disulfiram. Annu Rev Pharmacol Toxicol. 1981;21:575-96.

9. Lam JP, Mays DC, Lipsky JJ. Inhibition of recombinant human mitochondrial and cytosolic aldehyde dehydrogenases by two candidates for the active metabolites of disulfiram. Biochemistry. 1997;36:13748-54.

10. Johansson B. A review of the pharmacokinetics and pharmacodynamics of disulfiram and its metabolites. Acta Psychiatr Scand Suppl. 1992;369:15-26.

11. Skrott Z, Mistrik M, Andersen KK, Friis S, Majera D, Gursky J, Ozdian T, Bartkova J, Turi Z, Moudry P, et al. Alcohol-abuse drug disulfiram targets cancer via p97 segregase adaptor NPL4. Nature. 2017;552:194-9.

12. Chen D, Cui QC, Yang H, Dou QP. Disulfiram, a clinically used antialcoholism drug and copper-binding agent, induces apoptotic cell death in breast cancer cultures and xenografts via inhibition of the proteasome activity. Cancer Res. 2006;66:10425-33.

13. Doytcheva MA, Jeliazkova BG. Structure of copper (II) dithiocarbamate mixed-ligand complexes and their photoreactivities in alcohols. Spectrochim Acta A Mol Biomol Spectrosc. 2004;60:1299-305.

14. Cen D, Brayton D, Shahandeh B, Meyskens FL Jr, Farmer PJ. Disulfiram facilitates intracellular cu uptake and induces apoptosis in human melanoma cells. J Med Chem. 2004;47:6914-20.

15. Yip NC, Fombon IS, Liu P, Brown S, Kannappan V, Armesilla AL, Xu B, Cassidy J, Darling JL, Wang W. Disulfiram modulated ROS-MAPK and NFkappaB pathways and targeted breast cancer cells with cancer stem celllike properties. Br J Cancer. 2011;104:1564-74.

16. Xiao Zhang PH, Ding S, Sun T, Liu L, Han S, DeLeo AB, Sadagopan A, Guo W, Wang X. Induction of autophagy-dependent apoptosis in cancer cells through activation of ER stress: an uncovered anti-cancer mechanism by anti-alcoholism drug disulfram. Am J Cancer Res. 2019;9:1266-81.

17. Cong J, Wang Y, Zhang X, Zhang N, Liu L, Soukup K, Michelakos T, Hong T, Deleo A, Cai L, et al. A novel chemoradiation targeting stem and nonstem pancreatic cancer cells by repurposing disulfiram. Cancer Lett. 2017;409: 9-19.

18. Demaria S, Ng B, Devitt ML, Babb JS, Kawashima N, Liebes L, Formenti SC. lonizing radiation inhibition of distant untreated tumors (abscopal effect) is immune mediated. Int J Radiat Oncol Biol Phys. 2004;58:862-70.

19. Dewan MZ, Galloway AE, Kawashima N, Dewyngaert JK, Babb JS, Forment SC, Demaria S. Fractionated but not single-dose radiotherapy induces an immune-mediated abscopal effect when combined with anti-CTLA-4 antibody. Clin Cancer Res. 2009;15:5379-88.

20. Obeid M, Panaretakis T, Joza N, Tufi R, Tesniere A, van Endert P, Zitvogel L, Kroemer $\mathrm{G}$. Calreticulin exposure is required for the immunogenicity of gamma-irradiation and UVC light-induced apoptosis. Cell Death Differ. 2007; 14:1848-50.

21. Panaretakis T, Kepp O, Brockmeier U, Tesniere A, Bjorklund AC, Chapman DC, Durchschlag M, Joza N, Pierron G, van Endert P, et al. Mechanisms of pre-apoptotic calreticulin exposure in immunogenic cell death. EMBO J. 2009;28:578-90.

22. Perez CA, Fu A, Onishko H, Hallahan DE, Geng L. Radiation induces an antitumour immune response to mouse melanoma. Int J Radiat Biol. 2009; 85:1126-36.

23. Golden EB, Apetoh L. Radiotherapy and immunogenic cell death. Semin Radiat Oncol. 2015;25:11-7. 
24. Obeid M, Tesniere A, Ghiringhelli F, Fimia GM, Apetoh L, Perfettini $J$, Castedo M, Mignot G, Panaretakis T, Casares N, et al. Calreticulin exposure dictates the immunogenicity of cancer cell death. Nat Med. 2007;13:54-61.

25. Garg AD, Nowis D, Golab J, Vandenabeele P, Krysko DV, Agostinis P. Immunogenic cell death. DAMPs anticancer therapeutics:emerging amalgamation Biochim Biophys Acta. 1805;2010:53-71.

26. Galluzzi L, Buque A, Kepp O, Zitvogel L, Kroemer G. Immunogenic cell death in cancer and infectious disease. Nat Rev Immunol. 2017;17:97-111.

27. Krysko DV, Garg AD, Kaczmarek A, Krysko O, Agostinis P, Vandenabeele P. Immunogenic cell death and DAMPs in cancer therapy. Nat Rev Cancer. 2012;12:860-75

28. Casares N, Pequignot MO, Tesniere A, Ghiringhelli F, Roux S, Chaput N, Schmitt E, Hamai A, Hervas-Stubbs S, Obeid M, et al. Caspase-dependent immunogenicity of doxorubicin-induced tumor cell death. J Exp Med. 2005; 202:1691-701.

29. Dudek AM, Garg AD, Krysko DV, De Ruysscher D, Agostinis P. Inducers of immunogenic cancer cell death. Cytokine Growth Factor Rev. 2013; 24:319-33.

30. Fucikova J, Kralikova P, Fialova A, Brtnicky T, Rob L, Bartunkova J, Spisek R. Human tumor cells killed by anthracyclines induce a tumor-specific immune response. Cancer Res. 2011;71:4821-33.

31. Vanpouille-Box C, Alard A, Aryankalayil MJ, Sarfraz Y, Diamond JM, Schneider RJ, Inghirami G, Coleman CN, Formenti SC, Demaria S. DNA exonuclease Trex1 regulates radiotherapy-induced tumour immunogenicity. Nat Commun. 2017:8:15618.

32. Tesniere A, Panaretakis T, Kepp O, Apetoh L, Ghiringhelli F, Zitvogel L, Kroemer G. Molecular characteristics of immunogenic cancer cell death. Cell Death Differ. 2008;15:3-12.

33. Al-Hajj M, Wicha MS, Benito-Hernandez A, Morrison SJ, Clarke MF. Prospective identification of tumorigenic breast cancer cells. Proc Natl Acad Sci U S A. 2003;100:3983-8

34. Zhang X, Hu P, Ding SY, Sun T, Liu L, Han S, DeLeo AB, Sadagopan A, Guo W, Wang $X$. Induction of autophagy-dependent apoptosis in cancer cells through activation of ER stress: an uncovered anti-cancer mechanism by anti-alcoholism drug disulfiram. Am J Cancer Res. 2019;9:1266-81.

35. Hosea R, Hardiany NS, Ohneda O, Wanandi SI. Glucosamine decreases the stemness of human ALDH(+) breast cancer stem cells by inactivating STAT3. Oncol Lett. 2018;16:4737-44.

36. Ogino T, Wang X, Kato S, Miyokawa N, Harabuchi Y, Ferrone S. Endoplasmic reticulum chaperone-specific monoclonal antibodies for flow cytometry and immunohistochemical staining. Tissue Antigens. 2003;62:385-93.

37. Sabbatino F, Favoino E, Wang Y, Wang X, Villani V, Cai L, Yang L, Ferrone S, Ferrone CR. Grp94-specific monoclonal antibody to counteract BRAF inhibitor resistance in BRAF ${ }^{\mathrm{V} 600 \mathrm{E}}$ melanoma. J Transl Med. 2015;13:K12.

38. Pangrsic T, Potokar M, Stenovec M, Kreft M, Fabbretti E, Nistri A, Pryazhnikov E, Khiroug L, Giniatullin R, Zorec R. Exocytotic release of ATP from cultured astrocytes. J Biol Chem. 2007;282:28749-58.

39. Qin J, Kunda N, Qiao G, Calata JF, Pardiwala K, Prabhakar BS, Maker AV. Colon cancer cell treatment with rose bengal generates a protective immune response via immunogenic cell death. Cell Death Dis. 2017;8: e2584.

40. Zhou L, Sheng D, Wang D, Ma W, Deng Q, Deng L, Liu S. Identification of cancer-type specific expression patterns for active aldehyde dehydrogenase (ALDH) isoforms in ALDEFLUOR assay. Cell Biol Toxicol. 2019;35:161-77.

41. Phillips TM, McBride WH, Pajonk F. The response of CD24(-/low)/CD44+ breast cancer-initiating cells to radiation. J Natl Cancer Inst. 2006;98: 1777-85.

42. Duru N, Fan M, Candas D, Menaa C, Liu HC, Nantajit D, Wen Y, Xiao K, Eldridge A, Chromy BA, et al. HER2-associated radioresistance of breast cancer stem cells isolated from HER2-negative breast cancer cells. Clin Cancer Res. 2012;18:6634-47.

43. Li X, Lewis MT, Huang J, Gutierrez C, Osborne CK, Wu MF, Hilsenbeck SG, Pavlick A, Zhang X, Chamness GC, et al. Intrinsic resistance of tumorigenic breast cancer cells to chemotherapy. J Natl Cancer Inst. 2008;100:672-9.

44. Sultan M, Vidovic D, Paine AS, Huynh T, Coyle KM, Thomas ML, Cruickshank BM, Dean CA, Clements DR, Kim Y, et al. Epigenetic silencing of TAP1 in Aldefluor(+) breast Cancer stem cells contributes to their enhanced immune evasion. Stem Cells. 2018;36:641-54.

45. Hsu JM, Xia W, Hsu YH, Chan LC, Yu WH, Cha JH, Chen CT, Liao HW, Kuo CW, Khoo KH, et al. STT3-dependent PD-L1 accumulation on cancer stem cells promotes immune evasion. Nat Commun. 2018;9:1908.
46. Wang B, Wang Q, Wang Z, Jiang J, Yu SC, Ping YF, Yang J, Xu SL, Ye $X Z$, Xu C, et al. Metastatic consequences of immune escape from NK cell cytotoxicity by human breast cancer stem cells. Cancer Res. 2014; 74:5746-57.

47. Lu H, Clauser KR, Tam WL, Frose J, Ye X, Eaton EN, Reinhardt F, Donnenberg VS, Bhargava R, Carr SA, Weinberg RA. A breast cancer stem cell niche supported by juxtacrine signalling from monocytes and macrophages. Nat Cell Biol. 2014;16:1105-17.

48. Okuda H, Kobayashi A, Xia B, Watabe M, Pai SK, Hirota S, Xing F, Liu W, Pandey PR, Fukuda $K$, et al. Hyaluronan synthase HAS2 promotes tumor progression in bone by stimulating the interaction of breast cancer stemlike cells with macrophages and stromal cells. Cancer Res. 2012;72:537-47.

49. Neve RM, Chin K, Fridlyand J, Yeh J, Baehner FL, Fevr T, Clark L, Bayani N, Coppe JP, Tong F, et al. A collection of breast cancer cell lines for the study of functionally distinct cancer subtypes. Cancer Cell. 2006;10:515-27.

\section{Publisher's Note}

Springer Nature remains neutral with regard to jurisdictional claims in published maps and institutional affiliations.

Ready to submit your research? Choose BMC and benefit from:

- fast, convenient online submission

- thorough peer review by experienced researchers in your field

- rapid publication on acceptance

- support for research data, including large and complex data types

- gold Open Access which fosters wider collaboration and increased citations

- maximum visibility for your research: over $100 \mathrm{M}$ website views per year

At $\mathrm{BMC}$, research is always in progress.

Learn more biomedcentral.com/submissions 